\title{
Influence of the stiffness of beam-column connections on the structural analysis of reinforced concrete buildings
}

\author{
Influência da rigidez das ligações viga-pilar na \\ análise estrutural de edifícios em concreto armado
}
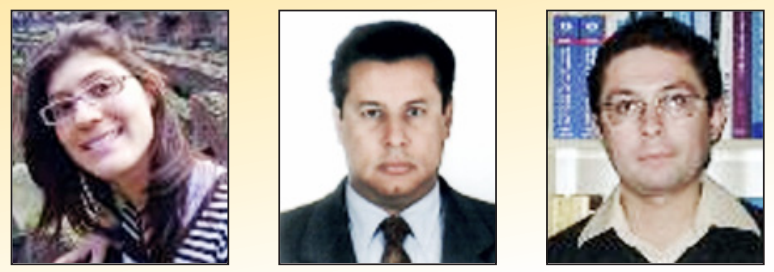

J. B. SANTOS a

julia.santos@ifg.edu.br

T. J. DA SILVA

tjdsilva@gmail.com

G. M. S. ALVA

alva_gerson@yahoo.com.br

\begin{abstract}
Conventional structural analysis of buildings in reinforced concrete is performed considering beam-column connections as rigid. However, experimental results prove the existence of relative rotations in beam-column connections of reinforced concrete structures, showing the partial transfer of bending moment. In this study the influence of the stiffness of beam-column connections on the global stability and in the column bending moments of buildings in reinforced concrete was investigated. A building was designed with rigid connections and deformable connections to identify the importance of considering the influence of the stiffness of the beam-column connections in the overall stability of monolithic and in the redistribution efforts in reinforced concrete structures. In order to determine the stiffness rotation of deformable connections, two analytical models available in literature were used, and a comparison between the results obtained by each analytical model was also performed. Based on the results, it is concluded that neglecting the influence of the stiffness of the beam-column connections on the analysis of monolithic reinforced concrete structures may result in different solutions compared to the real behavior of the structure. The stiffness values obtained with the analytical models usually differ from the condition of rigid connections, suggesting an adjustment on the standard consideration of rigid connections adopted by the computer programs of structural calculation.
\end{abstract}

Keywords: reinforced concrete structures, beam-column connection, stiffness rotation, partially rigid conections, monolithic connections.

\section{Resumo}

A análise estrutural convencional de edifícios em concreto armado é realizada considerando as ligações viga-pilar como rígidas. Entretanto, resultados experimentais comprovam a existência de rotações relativas nas ligações viga-pilar de estruturas de concreto armado, evidenciando a transmissão parcial de momento fletor. Neste trabalho foi investigada a influência da rigidez das ligações viga-pilar na estabilidade global de edifícios em concreto armado, e também, nos esforços dos pilares. Com o auxílio do programa comercial TQS, uma edificação foi calculada considerando ligações rígidas e ligações deformáveis, visando identificar a importância da consideração da influência da rigidez das ligações viga-pilar na estabilidade global e na redistribuição de esforços de estruturas monolíticas de concreto armado. Para determinação da restrição à rotação das ligações deformáveis, utilizaram-se dois modelos analíticos disponíveis na literatura, realizando-se, também, uma comparação entre os resultados obtidos pelos modelos. Com base nos resultados, conclui-se que negligenciar a influência da rigidez das ligações viga-pilar na análise de estruturas monolíticas em concreto armado pode gerar soluções muito diferentes do comportamento real da estrutura na prática. Os valores de rigidez obtidos pelos modelos analíticos utilizados diferem de forma não negligenciável da condição de ligações rígidas, sugerindo-se a adequação na consideração padrão de ligações rígidas adotada pelos programas computacionais de cálculo estrutural.

Palavras-chave: estruturas de concreto armado, ligação viga-pilar, rigidez à rotação, engastamento parcial, ligações monolíticas. 


\section{Introduction}

In terms of the technological advance and development of structural analysis programs, it is possible to design slenderer buildings. However, these structures may exhibit high lateral displacement, in addition to significant second-order effects. Thus, the global stability evaluation of multi-story buildings takes on a great importance in structural design. In recent years, several researches have been carried out to analyze the stiffness of beam-column connections influence on the global stability of precast concrete structures performed by Brazilian researchers. Among these researches, it can be highlighted Ferreira et al. [1], Ferreira et al. [2], Araújo et al. [3] and El Debs et al. [4]. Due to the absence of monolithism observed in these structures, the stiffness of connections is an essential factor regarding the influence of the structural behavior of buildings subjected to lateral loads.

At the international level, several experimental investigations are found in the specialized bibliography on monolithic beam-column connections, emphasizing their behavior when subjected to seismic loads. Among these studies, some of them considered the slippage of flexural reinforcement bars effects on the relative rotations between beam and column and on the global behavior of the connection [5-9]. Although there are several international studies dealing with the numerical simulation of beam- column joints via Finite Elements Method using 2D or 3D finite elements, models which apply springs in order to represent flexibility of the connections are still more attractive due to simplicity. In this context, there are models with rotational springs that simulate the effects of slippage of reinforcement bars [10-12] and models that use additional springs to represent the effect of joint distortion [13-15]. Even though they are more attractive due to the simplicity and low computational effort, these models still present difficulties with regard to the calibration of the parameters used by them and obstacles in being used in commercial software for analysis and design of reinforced concrete structures.

Simple analytical models which use only well known parameters and currently applied in the design of reinforced concrete structures are certainly more attractive for structural analysis. Among these, the model of Paultre et al. [8] and, more recently, the models presented in Sezen and Moehle [16], Sezen and Setzler [17], and Kwak and Kim [18] can be cited.

Despite many experimentally and analytically studies on beamcolumn connections in monolithic reinforced concrete structures, known as beam-column joints, there are few published studies on the influence of stiffness of these connections regarding the analysis of global stability of entire structures.

Connections in cast-in-situ concrete structures are usually stiffer compared to those ones in precast concrete, due to the existence of continuity between the structural elements which provides monolithism to the structure. In spite of this, experimental tests on reinforced concrete beam-column joints show the existence of relative rotations between beams and columns, according to Ferreira [19] and Alva [20]. These connections are theoretically treated as fully rigid, but in practice, the existence of these relative rotations causes a stiffness reduction in the connection.

Alva and El Debs [21] presented an analytical model in order to determine the relative rotations in beam-column connections of monolithic reinforced concrete structures. In the experimental vali- dation of the model, the authors compared the model results with experimental values and with results obtained by considering the connections as fully rigid. It can be seen in Figure 1 that the consideration of fully rigid connections may differ considerably from the actual behavior, even in monolithic connections.

Experimental investigation conducted by Lacerda [30] can be cited among the most recent national researches on precast connections. In this investigation, the influence of continuity reinforcement positioning on precast connections were analyzed. The results allowed to conclude that the specimens with reinforcement steel bars crossing the column presented higher stiffness than the specimens with reinforcement steel bars only in slab. In addition, a comparison was performed between the experimental results and those obtained by Ferreira et al. [1] analytical model. Recently, the Brazilian Code for design of precast concrete structures [24] has provided analytical expressions for the calculation of the secant bending stiffness for six typologies of connections.

Besides the local impacts derived from the stiffness reduction of the structure joints, changes in the global behavior of the building can be noticed. A modification in the connections stiffness alters the structural behavior under lateral loads. Consequently, it affects the lateral displacements and the second order effects on the building structure, modifying the design of the structural members. However, the influence of connections stiffness is not always verified in the structural analysis, neglecting the possible impacts on the behavior of the structure. This can be explained by the lack of more in-depth studies on the stiffness of monolithic reinforced concrete connections and, especially, its influence on overall structural behavior. In addition, the usual consideration that the monolithic connections are rigid does not arouse in engineers a concern about the influence of the connections stiffness in structural analysis.

An increase in the number of storeys in the structure leads to lateral displacements and second order effects become larger. Therefore, in multi-story structures, the influence of beam-column stiffness can be crucial on global stability (second-order effects).

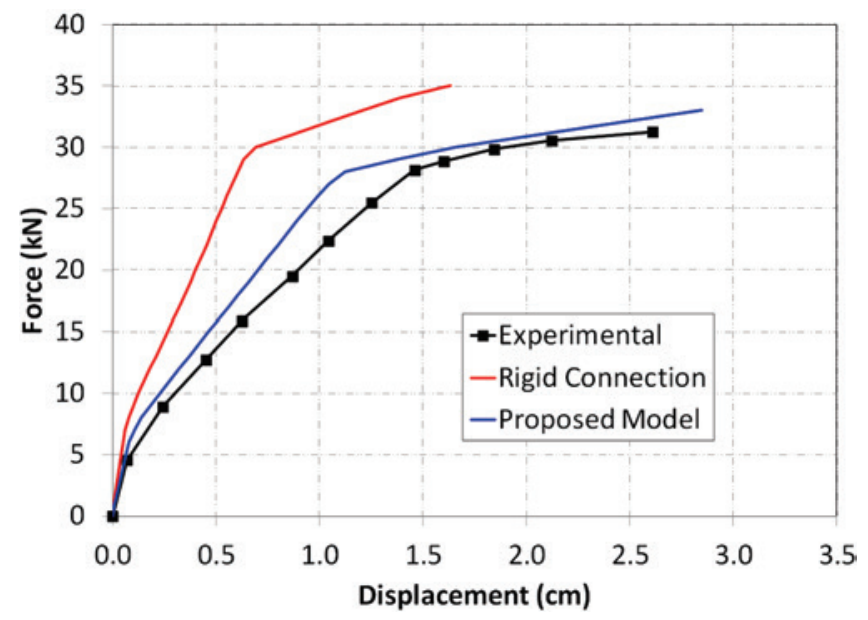

Figure 1

Comparison between experimental results of monolithic beam-column connection and numerical simulations using model proposed by Alva and El Debs [21] - Lee et al. [29]: specimen 2 


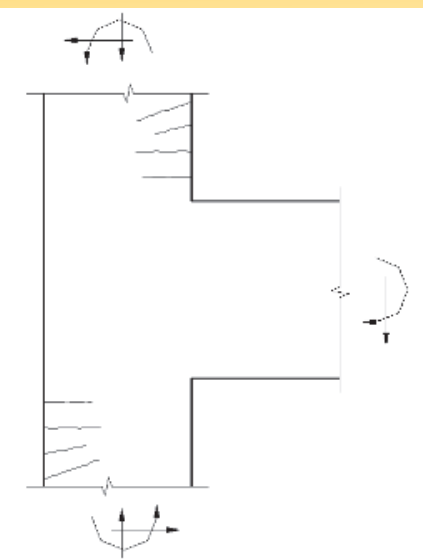

a) Cracking of column

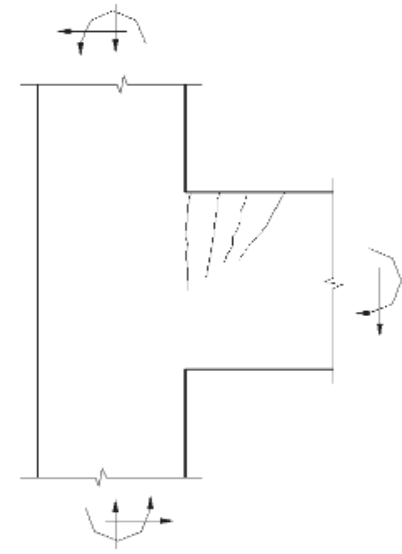

b) Cracking of beam

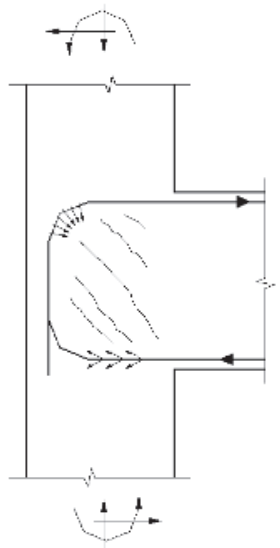

c) Cracking of joint

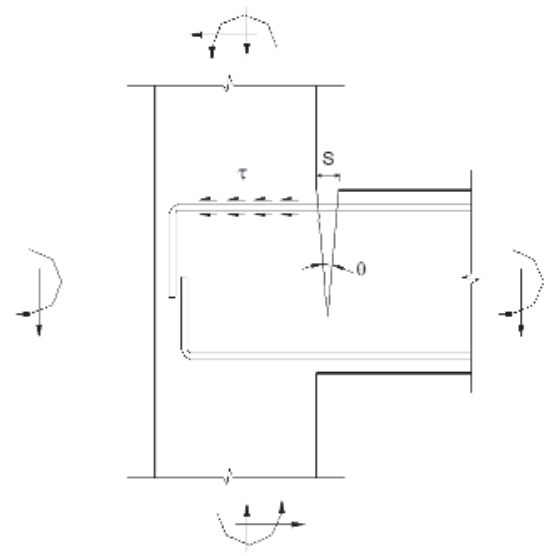

d) Slippage of reinforcement

Figure 2

Cracking and slippage of reinforcement in beam-column joints

\begin{abstract}
A better understanding upon the influence of beam-column stiffness on structural behavior may contribute to the development of structural projects closer to the reality of buildings behavior. Such methods may contribute to more safety in the design of reinforced concrete structures, especially of multi-floor buildings. In addition, the use of the available computational programs requires a better understanding of the impacts of the beam- column connections stiffness modification on the structural behavior of buildings.
\end{abstract}

\section{Beam-column connections in structural analysis}

\subsection{Initial considerations}

Structural analysis is a primordial procedure in the structural design of a building in reinforced concrete. It consists in obtaining the behavior of the structure subjected to dead and live loads and lateral forces (wind and earthquakes), determining the distributions of internal forces, strains and displacements in the structure, checking ultimate and serviceability limit states.

The behavior of beam-column connections influences the internal forces redistribution of the 3D frame structure, as well as in the design of all structural members. Thus, in the structural analysis, the influence of the connections stiffness must be treated with its proper importance, in order to be able to obtain internal forces and the design of the structural members in a manner that is compatible with the real structure.

The beam- column connections, also called beam-column joints, are regions of very complex structural behavior, where stress concentrations occur (normal stress and shear stress). According to Alva [20], there is the influence of many variables interacting on the joint strength capacity such as the reinforcement detailing, geometry of connected structural members, intensity of the internal forces, and finally strength of the materials (concrete and steel). According to experimental results obtained by Ferreira [19] and Alva [20], it is possible to observe the existence of relative rotations in the monolithic reinforced concrete beam-column connections. These rotations are caused by the slippage of flexural reinforcement of the beams inside the beam-column joints and by the cracking of concrete in these regions, as shown in Figure 2.

From the experimental and analytical results of some researches, highlighting Alva et al. [22], Ferreira [19], Ferreira et al. [1], Alva and

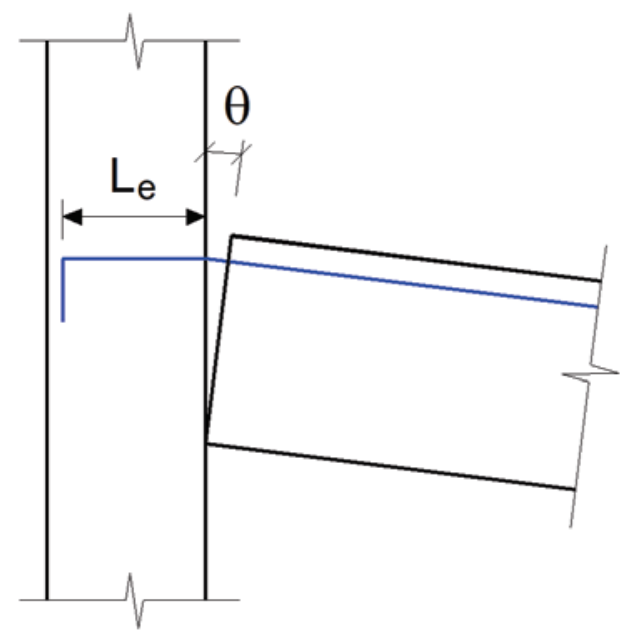

Elongation of beam bars along the length Le

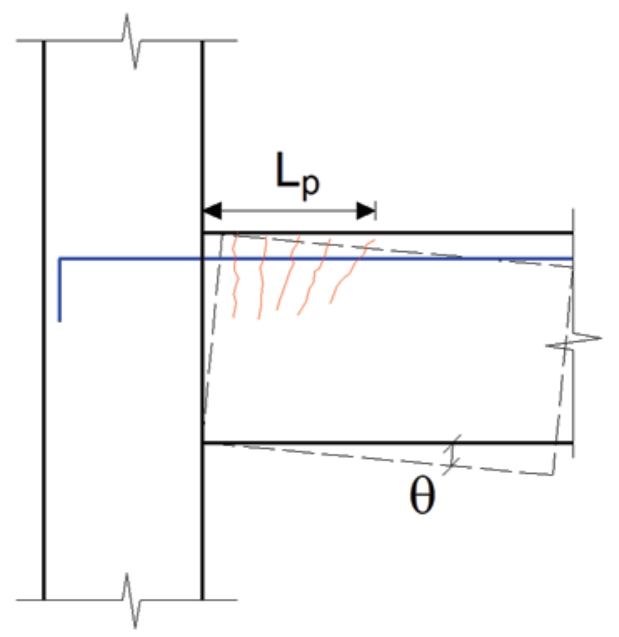
Bending deformations along the length $L p$ (D-region)

Figure 3

Deformation mechanisms in exterior beam-column connections [22] 


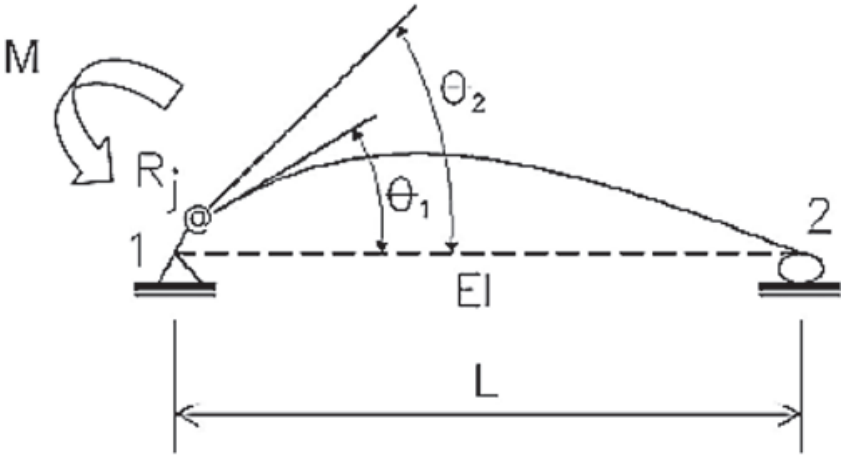

Figure 4

End-fixity factor - ABNT NBR 9062 [24]

El Debs [21], it can be concluded that the actual behavior of monolithic beam-column connections is not fully rigid, but partially restrained. As a result, considering the connections as rigid ends up overestimating the connections stiffness and, as a consequence, underestimating the lateral displacements of the structure.

\subsection{End-fixity factor}

The end-fixity factor (for bending moments) was initially presented by Monforton and Wu [23]. The authors developed a mathematical model to consider the effects of semi-rigid connections on the global behavior of plane frames. Subsequently, ABNT NBR 9062 [24] included the semi-rigid behavior of precast connections using the end-fixity factor $\alpha_{R}$.

The end-fixity factor is defined as the ratio of the chord rotation of the structural member $\left(\theta_{1}\right)$ to the sum of the chord rotation of the structural member $\left(\theta_{1}\right)$ and the rotation of the connection $\left(\theta_{2}\right)$, according to Figure 4. ABNT NBR 9062 [24] presents Equation 1 to determine the $\alpha_{R}$ value. This expression associates the bending stiffness of the beam-column connection $\left(R_{\text {sec }}\right)$ with the beam bending stiffness.

$$
\alpha_{R}=\frac{1}{1+\frac{3 .(E I)_{s e c}}{R_{s e c} L_{e f}}}
$$

where:

$(E I)_{\text {sec }}$ : secant bending stiffness of the beam according to ABNT NBR 6118 [25];

$\mathrm{L}_{\text {ef: }}$ effective span between supports (or the distance between rotation centers of the supports);

$R_{\text {sec }}$ : secant bending stiffness of the beam-column connection. The bending stiffness of the beam-column connection is obtained by its moment-rotation curve.

Nonlinear behavior of the connections can be considered by simplified linear analysis using the secant stiffness $\left(R_{\text {sec }}\right)$, as shown in the Figure 5. The relative rotation should be measured at the rotation center of the support. In order to determine the secant stiffness

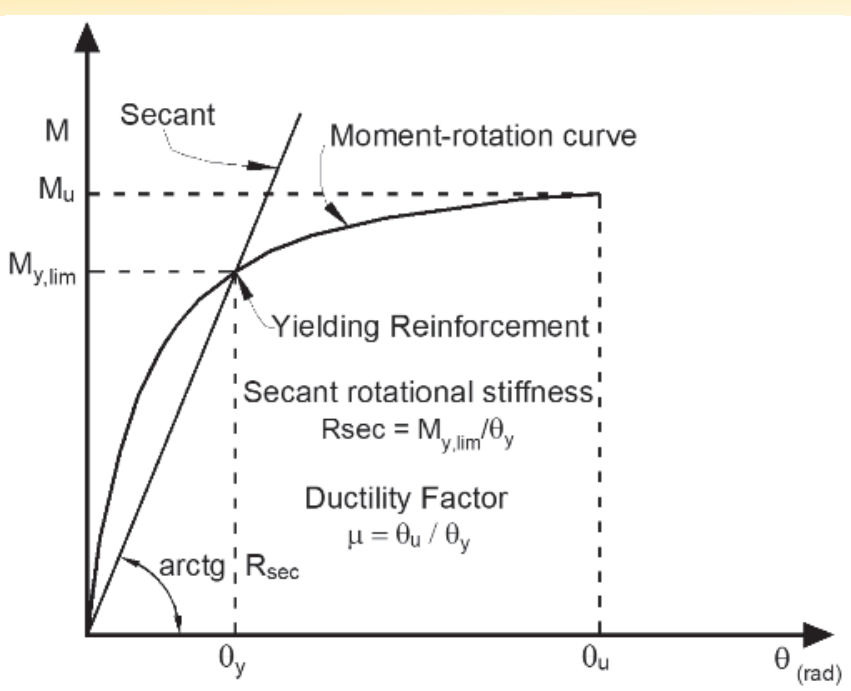

Figure 5

Moment-rotation relationship of precast concrete beam-column connections - Brazilian Code [24]

of the connections, the analytical models found in the literature for beam- column connections can be used.

Table 1 shows the classification of precast connections according to ANBT NBR 9062 [24] as function of the element ends flexural rigidities. A very large gap is observed for the connections stiffness consideration. In this context, Ferreira et al. [2] proposed a connection classification system subdivided in five different zones, as indicated in Table 2. In this table, $M_{E}$ is the moment mobilized by the connection and $M_{R}$ is the fixed end moment.

\subsection{Analytical models}

Two analytical models were used to determine the beam-column connections stiffness in this paper: i) Ferreira et al. [1] model; ii) Alva and El Debs [21] model.

Ferreira et al. [1] model was originally developed for precast beamcolumn connections with continuity reinforcement. In this model, the relative rotation in the beam-column connection is induced by two deformation mechanisms: the elongation of continuity reinforcement bars and the occurrence of bending cracks in the connection region (as shown in Figure 3). The comparison of the theoretical values

\section{Table 1}

Classification of connections for precast structures - adapted from [24]

\begin{tabular}{|c|c|}
\hline Connection type & End-fixity factor $\left(\alpha_{R}\right)$ \\
\hline Pinned & $\alpha_{R}<0,15$ \\
\hline Semi-rigid & $0,15 \leq \alpha_{R} \leq 0,85$ \\
\hline Fixed & $\alpha_{R}>0,85$ \\
\hline
\end{tabular}

\section{Table 2}

Classification system of connections for precast structures - adapted de [2]

\begin{tabular}{|c|c|c|c|}
\hline Zone & $\begin{array}{c}\text { End-fixity factor } \\
\left(\alpha_{R}\right)\end{array}$ & $\begin{array}{c}\text { Partially restrained } \\
\text { coefficient }\left(M_{E} / M_{R}\right)\end{array}$ & Classification of connection \\
\hline I & $0 \leq \alpha_{R}<0,14$ & $0 \leq M_{E} / M_{R}<0,2$ & Pinned \\
\hline$I$ & $0,14 \leq \alpha_{R}<0,4$ & $0,2 \leq M_{E} / M_{R}<0,5$ & Semi-rigid low-strength \\
\hline III & $0,4 \leq \alpha_{R}<0,67$ & $0,5 \leq M_{E} / M_{R}<0,75$ & Semi-rigid medium-strength \\
\hline IV & $0,67 \leq \alpha_{R}<0,86$ & $0,75 \leq M_{E} / M_{R}<0,9$ & Semi-rigid high-strength \\
\hline$V$ & $0,86 \leq \alpha_{R}<1$ & $0,9 \leq M_{E} / M_{R}<1$ & Fully rigid \\
\hline
\end{tabular}




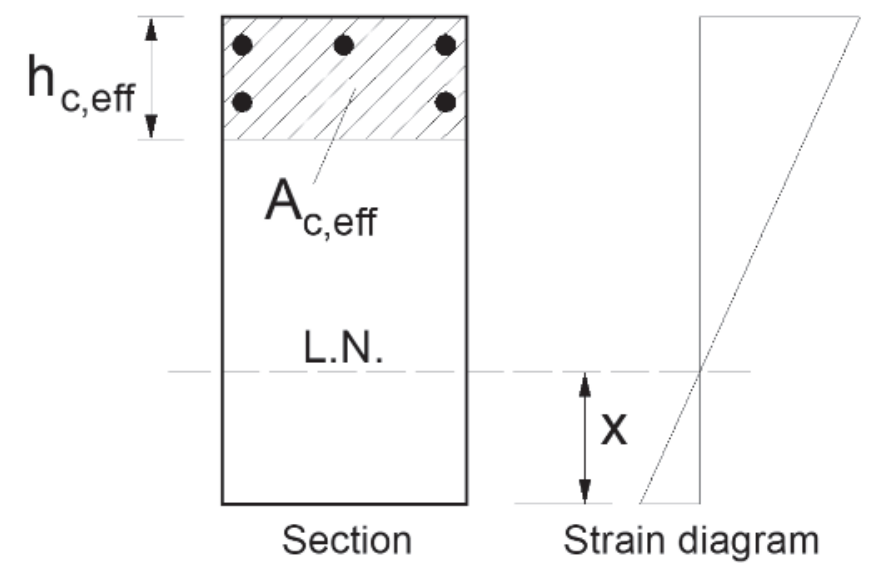

Figure 6

Definition of effective area $A_{c, \text { eff }}$ for prediction of crack spacing

with experimental results proved that the model can also be used in monolithic connections, presenting good values correlations, as presented in Alva et al. [22]. Equation 2 allows the determination of the moment-rotation curve until the yielding moment:

$\theta=\left[\left(\frac{M}{E_{c s} \cdot I_{e q}}\right) L_{p}+\left(\frac{\sigma_{s}}{E_{s} \cdot d}\right) L_{e}\right] \cdot\left(\frac{M}{M_{y}}\right)^{0,5}$

where

$\theta$ is the relative rotation between beam and column;

$M$ is the bending moment at the beam end;

$\mathrm{E}_{\mathrm{cs}}$ is the secant modulus of elasticity of the concrete;

$I_{\text {eq }}$ is the effective moment of inertia of the beam (Branson's formula);

$L_{p}$ is the connection region length, approximately equal to effective depth of the beam in monolithic beam-column connections;

$\sigma_{\mathrm{s}}$ is the stress on the tensioned reinforcement of the beam (bending reinforcement);

$\mathrm{E}_{\mathrm{s}}$ is the elasticity modulus of the steel;

$d$ is the effective depth of the beam;

$L_{e}$ is the embedded length of bending reinforcement of the beam in the column;

$M_{y}$ is the flexural strength of the connection, related to the yielding moment.

Material nonlinearity is considered in a simplified linear analysis using the secant bending stiffness of the connection, which can be deducted from Equation 2:

$R_{s e c}=\left[\frac{L_{p}}{E_{c s} \cdot I_{I I}}+\frac{L_{e}}{0,9 \cdot E_{s} \cdot A_{s} \cdot d^{2}}\right]^{-1}$

where

$\mathrm{R}_{\mathrm{sec}}$ is the secant bending stiffness of the connection;

$I_{\text {II }}$ is the moment of inertia of the cracked transformed section of the beam;

$A_{s}$ is the area of longitudinal bending reinforcement of the beam.

The model proposed by Alva and El Debs [21] has the same conceptual basis of Ferreira et al. [1] model, but considers the bondslip behavior of beam reinforcement bars inside the column and properties that interfere in the total slip caused by cracking of the beam, which are not contemplated in the Ferreira et al. [1] model.
The moment-rotation curve applicable until the end of the elastic range $\left(M \leq M_{y}\right)$ is given by Equation 4:

$\theta=C_{1} \cdot M^{2}+C_{2} \cdot\left(\frac{1}{r}\right)$

where

$C_{1}=\frac{\emptyset}{8 \cdot E_{s} \cdot \tau_{b y} \cdot(d-x) \cdot A_{s}{ }^{2} \cdot z^{2}}$

$C_{2}=0,5 .\left(L_{p}+s_{R}\right)$

$\phi$ is the bar diameter of the longitudinal reinforcement of the beam; $\tau_{\text {by }}$ is the bond stress in the elastic range [16-17], equal to $\sqrt{f_{c}}$, with $\mathrm{f}_{\mathrm{c}}$ in $\mathrm{MPa}$;

$f_{c}$ is the column concrete compressive strength;

$x$ is the neutral axis depth (cracked section);

$z$ is the lever arm between the tension and compression forces in the section beam:

$z=d-\frac{x}{3}$

$\mathrm{S}_{\mathrm{r}}$ is the crack spacing in the connection region, which can be obtained by expressions found in specialized literature, presented in Borosnyói and Balázs [26], or by expressions of codes for design, such as Eurocode 2 [27].

$1 / r$ is the curvature at the beam end is the curvature of beam section calculated from the average reinforcement strain in the elastic range (with tension stiffening) or from the usual design calculations for reinforced concrete sections (with equilibrium and compatibility equations). The yielding moment My can be evaluated by $M_{y}=0,9 \cdot d \cdot A_{s} \cdot f_{y}$ or by $M_{y}=A_{s} \cdot f_{y} \cdot z$, where fy is the yield strength of the steel of bending reinforcement of the beam.

The expression to calculate the crack spacing presented by Eurocode 2 [27] is given by the Equation 5 :

$s_{R}=k_{3} \cdot c+\frac{k_{1} \cdot k_{2} \cdot k_{4} \cdot \emptyset}{\rho_{e f f}}$

where

$\mathrm{S}_{\mathrm{R}}$ is the crack spacing;

$\phi$ is the diameter of longitudinal bending reinforcement of the beam; $\mathrm{k}_{1}$ is a coefficient which considers bond properties of the reinforcement steel bars (equal to 0,8 for high-bond bars and equal 1,6 for plane surface bars);

$\mathrm{k}_{2}=0,5$;

$\mathrm{k}_{3}=3,4$;

$\mathrm{k}_{4}=0,425$;

$\mathrm{c}$ is the concrete cover;

$\rho_{\text {eff }}=\frac{A_{s}}{A_{c, e f f}}$

$A_{c, \text { eff }}$ is the effective tension area of concrete (see Figure 6).

From Equation 4, the secant bending stiffness of the connection obtained by Alva and El Debs [21] model is:

$R_{s e c}=\left[\frac{0,5 \cdot\left(L_{p}+s_{R}\right)}{E_{c s} \cdot I_{I I}}+\frac{\emptyset \cdot f_{y}}{8 \cdot E_{s} \cdot \tau_{b y} \cdot(d-x) \cdot A_{s} \cdot z}\right]^{-1}$

\section{Numerical simulations}

\subsection{Initial informations}

Numerical simulations of a building structure were carried out 


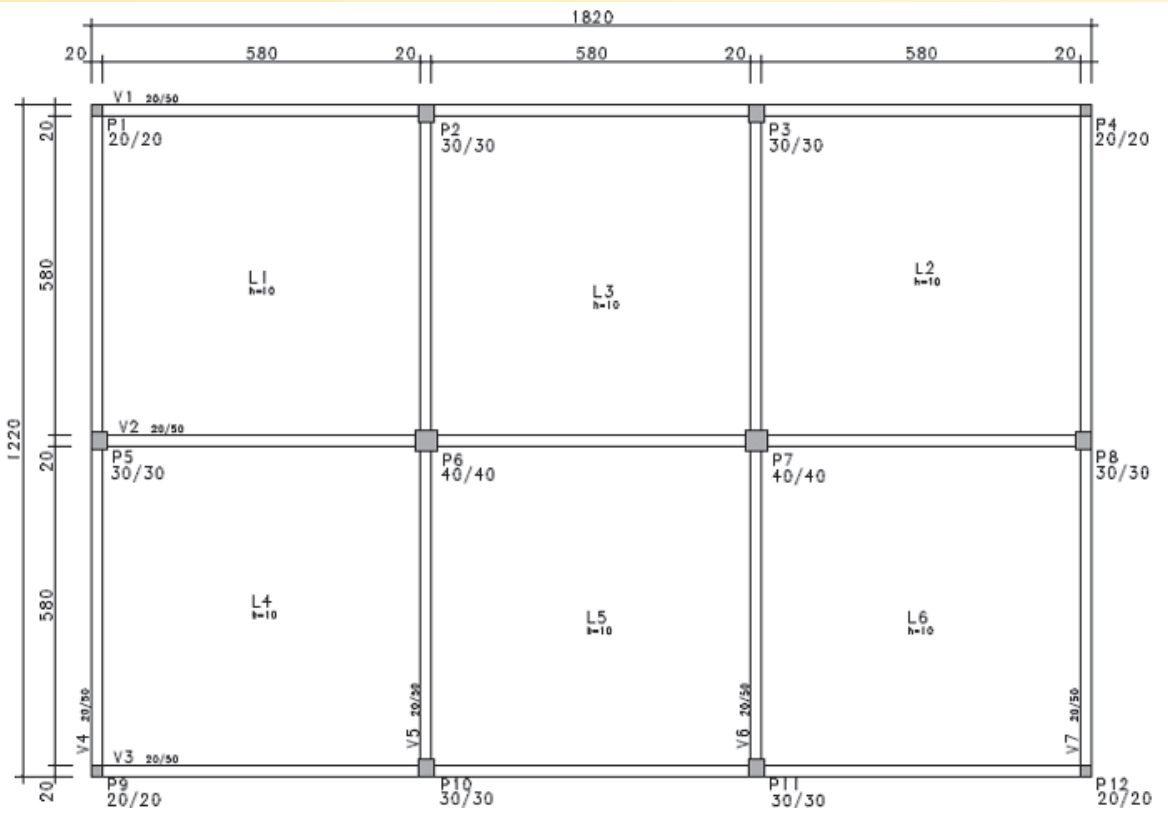

Figure 7

Typical floor plan of five-storey building (dimensions in $\mathrm{cm}$ )

considering the beam-column connections as fully rigid and partially restrained. In order to determine the secant stiffness and the endfixity factor $\left(\alpha_{\mathrm{R}}\right)$ of the connections, Ferreira El Debs et al. [1] and Alva and El Debs [21] models were used. The results of the global stability analysis (second-order global effects) and internal forces in the columns are compared for the both types of connections (fully rigid and partially restrained), aiming to emphasize the importance of considering the flexibility of the beam-column connections in structural analysis of monolithic reinforced concrete structures. Numerical simulations of a nineteen and five storey building were carried out, trying to identify differences in the influence of the connections flexibility on tall and low buildings (symmetric-plan buildings). Figures 7 and 8 contain the typical floor plan for 19-storey and 05 -storey buildings. In order to determine the dimensions of the cross-section columns, a preliminary estimate was performed according to the vertical loads acting on these structural members.

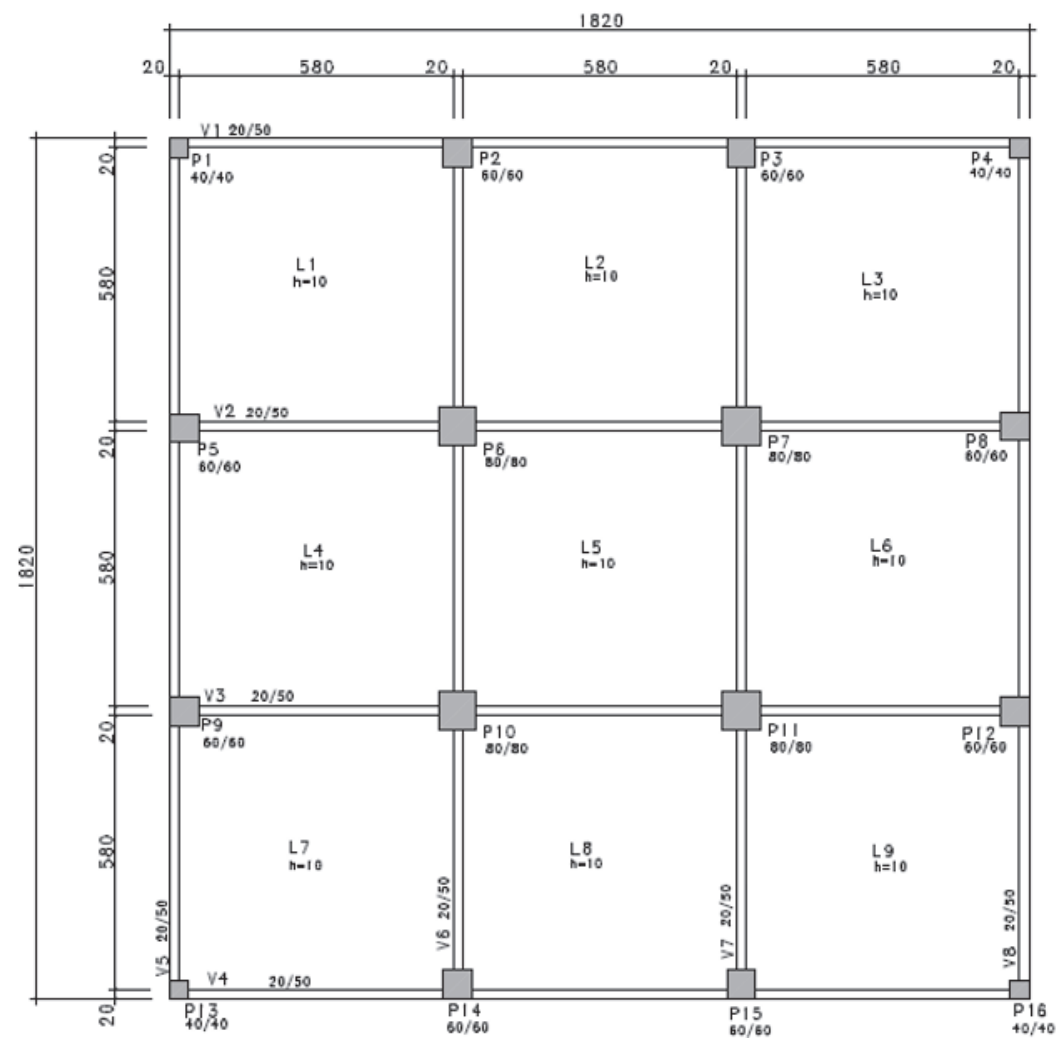

Figure 8

Typical floor plan of nineteen-storey building (dimensions in $\mathrm{cm}$ ) 


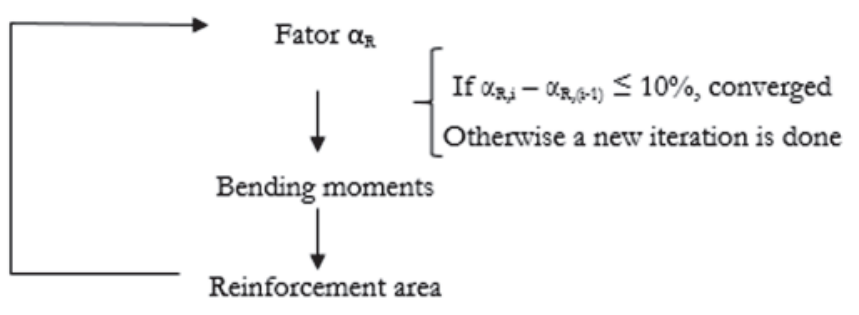

\section{Figure 9}

Algorithm used to determine the end-fixity fator $\alpha_{R}$ of the connections

These numerical simulations were performed in the software CAD/ TQS $®$ (version 18), which considers the influence of the beam-column connections stiffness by the end-fixity factor values which modify the stiffness matrix of 3D frame element in the structural analysis. It is worth emphasizing that the computational program performs numerous load combinations and uses the envelopes of internal forces for the design of the structural members. Thus, it has not been indicated in this paper which envelope was critical for the design of each structural member. Only the final results were presented.

The procedure used to consider this flexibility of the connections is described as follows. First, the numerical simulation of the building with fully rigid connections $\left(\alpha_{R}=1.0\right)$ is performed. Then, based on the reinforcement areas obtained from this structural analysis, the $\alpha_{R}$ value was determined for each connection. By performing a new simulation considering connections as partially restrained in the structural analysis, there will be a redistribution of internal forces in the structure, with changes in the reinforcement of beam-column connections, leading to different values of $\alpha_{R}$ for the connections. Therefore, it is an iterative process, which was repeated until the percentage difference between the $\alpha_{R}$ values of the current iteration in relation to the previous iteration is less than $10 \%$ as shown in Figure 7. The iterative process was performed manually (without automation).

\subsection{Input data}

The building structures were designed considering the concrete

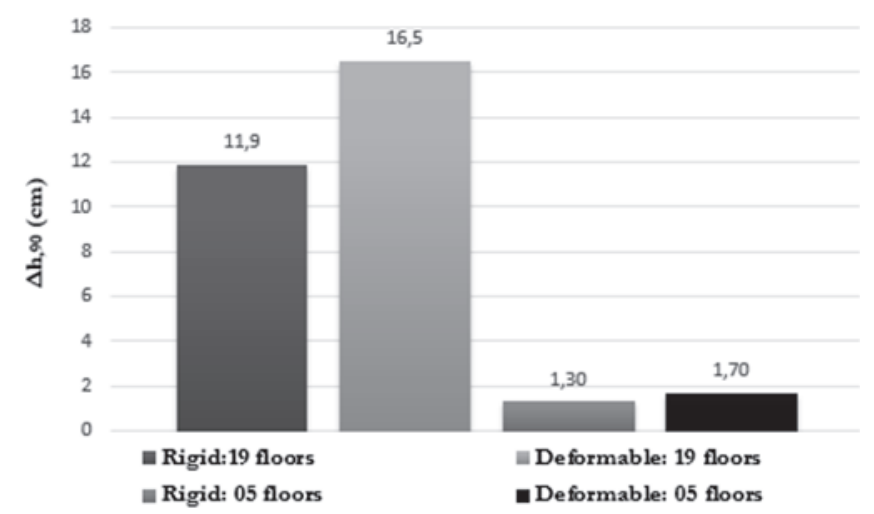

\section{Figure 10}

Ferreira et al. [1] model: lateral displacements for nineteen-storey and five-storey buildings, considering perfectly rigid and partially restrained connections compressive strength equal to $25 \mathrm{MPa}$ and environmental aggression level II. Dead loads on the typical floor slabs was derived from the self-weigth added to a load of $1,0 \mathrm{kN} / \mathrm{m}^{2}$ in order to consider additional permanent loads (floor covering). The dead loading of roof slabs was adopted equal to $1.0 \mathrm{kN} / \mathrm{m}^{2}$ to consider the existence of a roof with fiber cement sheet. According to ABNT NBR 6120 [28], the live load assumed for typical floor slabs was $2.0 \mathrm{kN} / \mathrm{m}^{2}$ (offices) and for roof slabs was $0.5 \mathrm{kN} / \mathrm{m}^{2}$.

The load used for the typical floor beams and foundation was the self-weight plus the weight of wall of $2.50 \mathrm{~m}$ in height, composed of clay blocks (thickness: $15 \mathrm{~cm}$ ). For the roof beams, it was considered a small wall of $0.5 \mathrm{~m}$ in height composed of clay blocks (thickness: $15 \mathrm{~cm}$ ). For typical and roof floors beams, there is still the loading portion from concrete slabs.

The critical direction of global stability was for wind acting at $90^{\circ}$. For the evaluation of global second order effects, the approximated procedure proposed by NBR 6118 was used, which applies the coefficient $\gamma_{z}$. The lateral displacement at the top of the structure for this critical wind direction was analyzed, as well as the values of the coefficient $\gamma_{z}$. Results for other wind directions were not analyzed in this paper.

Alva and El Debs [21] model was proposed for reinforced concrete monolithic beam-column connections. The relative rotations in the beam-column connection result from two deformation mechanisms: slippage of flexural reinforcement of the beams inside the column and the formation of bending cracks in the connection region. A good correlation between the theoretical values provided by the model proposed by Alva and El Debs [21] with experimental results was found. More information on these two analytical models are available in $[1,21]$.

In this paper, the influence of beam-column connections stiffness on lateral displacements of the structure, on second-order global effects (with the coefficient $\gamma_{z}$ ) and also on longitudinal reinforcement of the columns was verified. Clearly, beam-column connections stiffness also have impact on other structural elements (such as beams) and on other internal forces (such as shear forces). However, the choice of the analyzed results was made considering the importance of the impact of connection stiffness values on the global stability of the structure, as well as its consequent influence upon the amount of longitudinal reinforcement of the columns due to internal forces redistribution.

\section{Results and discussions}

\subsection{Ferreira et al. [1] model}

For the 19-storey building, concerning the roof floor connections, values for $\alpha_{R}$ ranging from 0,41 to 0,50 were obtained. According to Ferreira et al. [2] classification, these connections are semi-rigid with mediumstrength. In connections of the typical floor, $\alpha_{R}$ values ranging from 0.64 to 0.80 were achieved. Thus, these connections are classified as semirigid connections with medium-strength and high-strength.

For the 05-storey building, in roof floor connections, values of $\alpha_{R}$ varying from 0,49 to 0,52 were obtained, which are classified as semi-rigid with medium-strength, according to the classification of Ferreira et al. [2]. For the connections of the typical floor, $\alpha_{R}$ values ranging from 0.49 to 0.72 were attained, which classifies these 


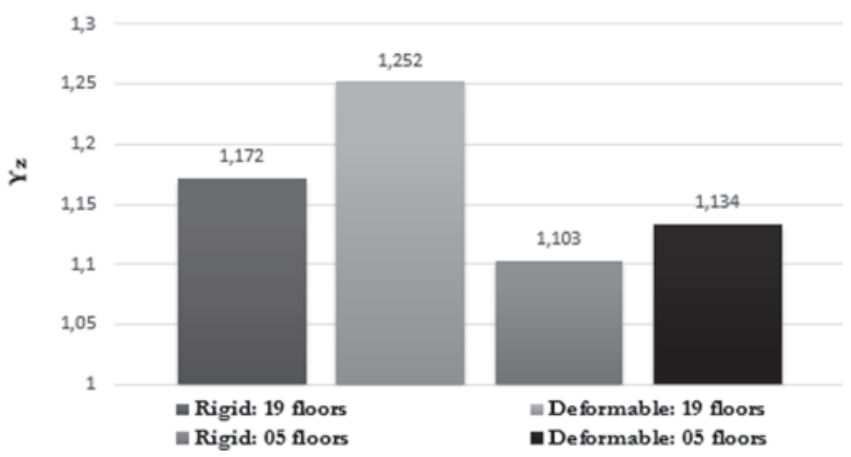

Figure 11

Ferreira et al. [1] model: coefficient $\gamma_{z}$ for for nineteenstorey and five-storey buildings, considering perfectly rigid and partially restrained connections

connections as semi-rigid with medium-strength and high-strength. Subsequently, a comparison of the global stability results obtained for the structure with rigid connections and for the structure with deformable connections using Ferreira et al. [1] model was presented (for the 19-storey building, and also for the 05-storey building). Figure 10 shows the lateral displacement at the top of the 19-storey structure. It can be noticed had a $38 \%$ increase from rigid connections to the deformable connections situation. For the 05 -storey structure, there was a $31 \%$ increase in the displacements value.

Figure 11 presents the coefficient $\gamma_{z}$ values for the 19-storey structure, which exhibited a variation from 1,172 to 1,252 considering deformable connections. For 05-storey structure, the increase was from 1,103 to 1,134 .

It is possible to notice that, in the case of 19-storey building, lateral displacements and the coefficient $\gamma_{z}$ percentage increases were higher in comparison with 05-storey building, as expected. In buildings higher than those analyzed in this paper, the influence on connections stiffness reducing may result in more critical situations for global stability (second-order effects).

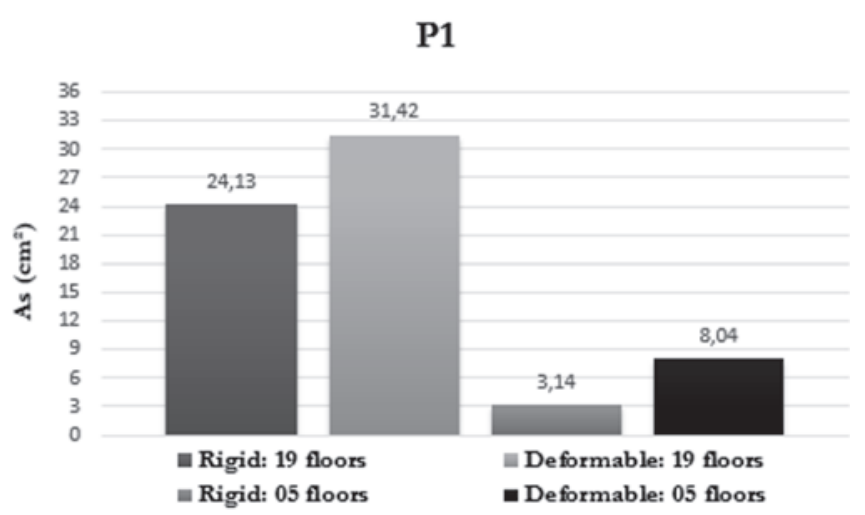

Figure 12

Ferreira et al. [1] model: longitudinal reinforcement of column P1 for nineteen-storey and five-storey buildings, considering perfectly rigid and partially restrained connections

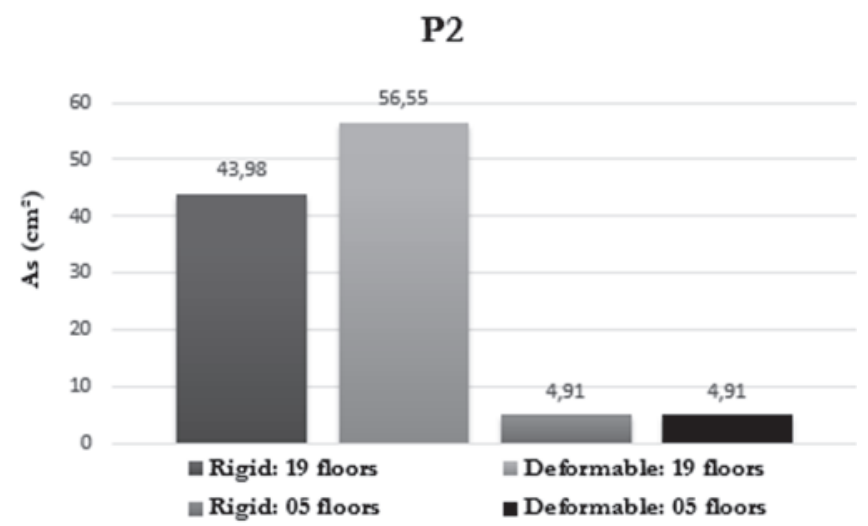

Figure 13

Ferreira et al. [1] model: longitudinal reinforcement of column P2 for nineteen-storey and five-storey buildings, considering perfectly rigid and partially restrained connections

Figures 12,13 and 14 show comparative graphs related to the area of longitudinal reinforcement in columns $\mathrm{P} 1, \mathrm{P} 2$ and $\mathrm{P} 6$ respectively. For the 19-storey structure, in all the columns, there was a $30 \%$ increase in the amount of reinforcement when the connections deformability was considered. For the 05-storey structure, there was an increase of $256 \%$ reinforcement for the P1 column, $24 \%$ for the P6 column, and there was no change for the P2 column.

\subsection{Alva and El Debs [21] model}

For the 19-storey building, concerning the roof floor connections, values for $\alpha_{R}$ ranging from 0,57 to 0,65 were obtained. According to Ferreira et al. [2] classification, these connections are semi-rigid with medium-strength. In connections of the typical floor, $\alpha_{R}$ values ranging from 0.73 to 0.85 were achieved, which classifies these connections as semi-rigid with high-strength.

For the 05-storey building, in the roof floor connections, values

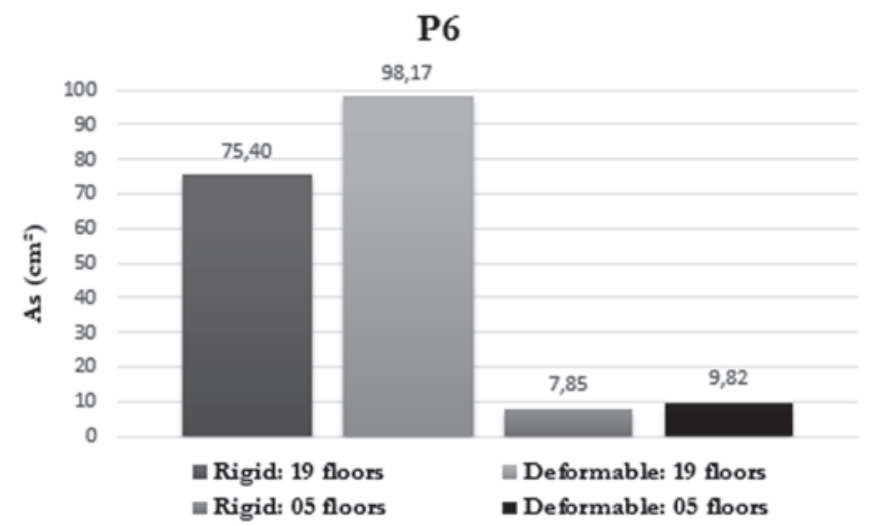

Figure 14

Ferreira et al. [1] model: longitudinal reinforcement of column P6 for nineteen-storey and five-storey buildings, considering perfectly rigid and partially restrained connections 


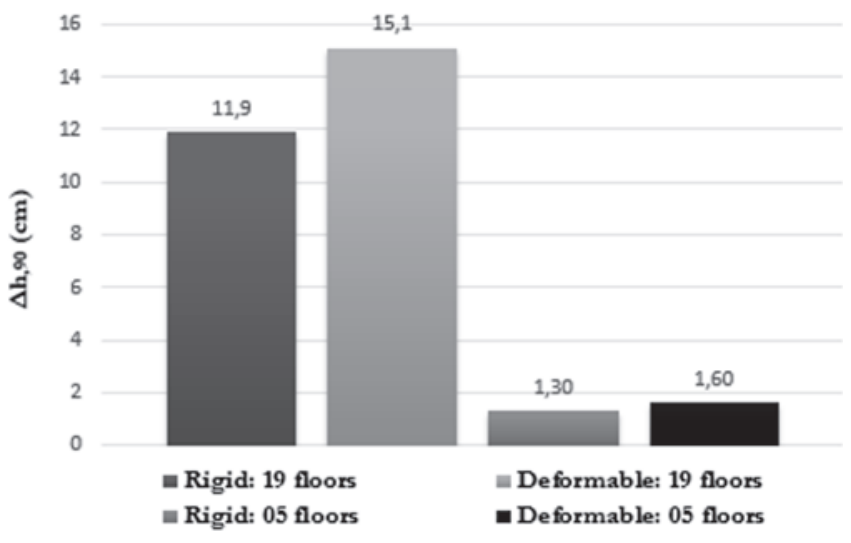

Figure 15

Alva and El Debs [21] model: lateral displacements for nineteen-storey and five-storey buildings, considering perfectly rigid and partially restrained connections

of $\alpha_{R}$ varying from 0,55 to 0,71 were obtained, which, according to the classification of Ferreira et al. [2], classifies these connections as semi-rigid with medium-strength and high-strength. For connections of the typical floor, $\alpha_{R}$ values ranging from 0.57 to 0.78 were attained. In this case, these connections are classified as semi-rigid with medium-strength and high-strength.

Figure 15 shows the lateral displacement at the top of the 19-storey building. It can be notice in this figure that the displacements for deformable connections situation are $27 \%$ larger than for rigid connections situation. For the 05 -storey building, this increase was about $23 \%$. In Figure 16 the values of coefficient $Y_{z}$ are presented. For the 19-storey building, the value of 1,172 was obtained in the case of rigid connections and 1,227 referring to deformable connections. For the 05-storey building, the coefficient $Y_{z}$ ranges from 1.103 (rigid connections) to 1,134 (deformable connections).

Figure 17, 1819 show comparative graphs related to the longitudinal reinforcement area of the columns $\mathrm{P} 1, \mathrm{P} 2$ and $\mathrm{P} 6$, respectively. For the 19-storey building, in the P1 and P4 columns there was

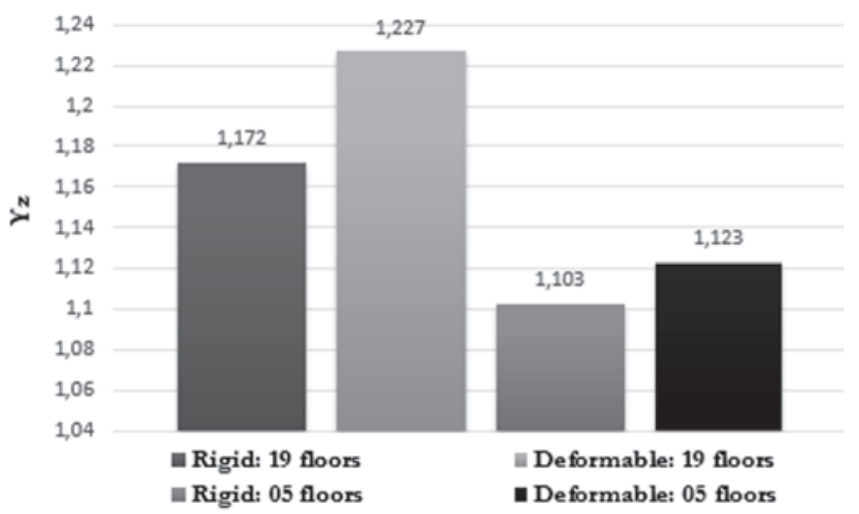

Figure 16

Alva and El Debs [21] model: coefficient $\gamma_{z}$ for nineteen-storey and five-storey buildings, considering perfectly rigid and partially restrained connections

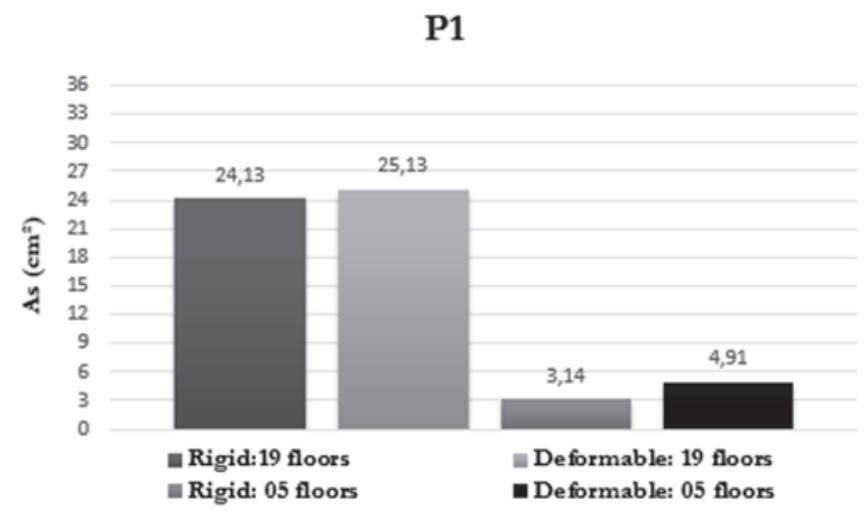

Figure 17

Alva and El Debs [21] model: longitudinal reinforcement of column $\mathrm{Pl}$ for nineteen-storey and five-storey buildings, considering perfectly rigid and partially restrained connections

an increase of only $4 \%$ in reinforcement when the deformability of connections was considered. For the P2 column, this increase was $29 \%$. For the 05 -storey structure, when the deformability of connections was considered, there was an increase in longitudinal reinforcement area only for the P1 column, which was $56 \%$.

\subsection{Comments about analytical models}

Observing the results obtained from the numerical simulations that consider the deformability of the connections in the structural analysis, some observations can be made on the analytical models discussed. The $\alpha_{R}$ values obtained by Alva and El Debs [21] model are larger than those obtained by Ferreira et al. [1] model, reaching $59 \%$ of differences. It was observed that the rotations obtained by Ferreira et al. [1] model are larger when compared to the Alva and El Debs [21] model. The differences between the models can be visualized in Equations 2 and 4.

\section{P2}

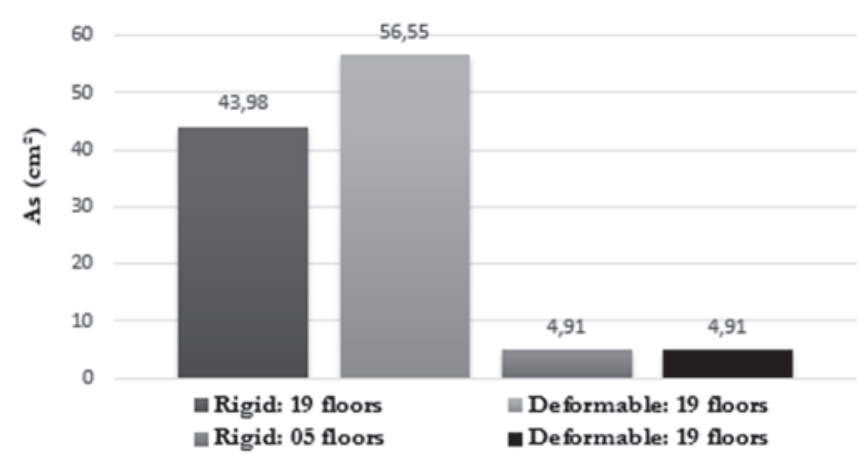

Figure 18

Alva and El Debs [21] model: longitudinal reinforcement of column P2 for nineteen-storey and five-storey buildings, considering perfectly rigid and partially restrained connections 
P6

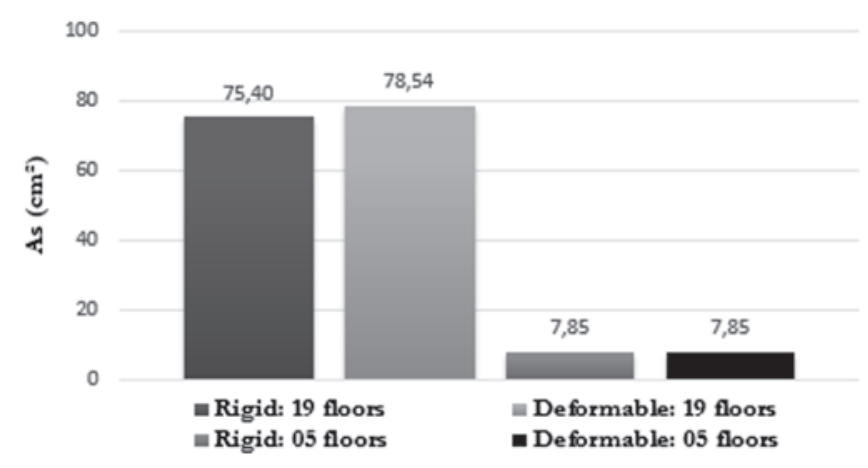

Figure 19

Alva and El Debs [21] model: longitudinal reinforcement of column P6 for nineteen-storey and five-storey buildings, considering perfectly rigid and partially restrained connections

Alva and El Debs [21] model considers important properties in bond-slip behavior of flexural reinforcement of the beam inside the column, differing from Ferreira et al. [1] model, in which the relative rotation corresponding to this deformation mechanism is exclusively attributed to the elongation of beam steel bars inside the column in embedded length.

\section{Conclusions}

According to the results obtained by the analytical models discussed in this paper, it was observed that the consideration of connections deformability can diverge in a relevant way with the rigid connections conventional hypothesis. In numerical simulations, $\alpha_{R}$ values lower than $50 \%$ were obtained in some connections. It was also verified that the roof floor connections have inferior stiffness when compared to the connections of the typical floor. This fact is attributed to the lower reinforcement ratios obtained for roof beams.

The existence of less stiff connections results in more critical situations for global stability of the structure and also for the reinforcement of the columns. In general, increases in the global stability parameters (second-order effects) due the consideration of partially rigid connections can lead to different solutions in the structural design when compared to solutions obtained by assuming the hypothesis of fully rigid connections.

Regarding the analytical models used in this paper, it was observed that Alva and El Debs [21] model results in stiffer values of the connections when compared to Ferreira et al. [1] model.

The analytical models used to determine the stiffness of beamcolumn connections in monolithic structures of reinforced concrete were developed for connections without the presence of slabs. The existence of slab may cause an increase in stiffness in the beamcolumn connection, besides reducing cracking in the beam, which is not considered in the models used in this paper.

Although monolithic beam-column connections are commonly treated as fully rigid, experimental results have already shown that there are relative rotations in these connections. The existence of a lower stiffness in the partially restrained beam-column connections causes a redistribution of internal forces in the structure, resulting in higher values for global stability parameters (second-order effects), for positive bending moments in the span of beams and for longitudinal reinforcement area of the columns. In addition, there are tools in the commercial computational programs for the calculation of concrete structures that consider such influence. It is up to the structural engineer to use this option with good judgment when considering the stiffness of connections in the structural analysis. Considering the results obtained in this research, it is recommended that the stiffness of the beam-column connections be taken into account even in cast-in-situ concrete structures design (monolithic structures). Structural analysis more realistic by taking into account the deformability of the connections, as well as providing greater structural safety.

\section{Acknowledgments}

To CAPES for financial support and to the engineer Rodrigo Nurnberg of TQS company, for the thoughtful support on the computational program.

\section{References}

[1] FERREIRA, M.A.; EL DEBS, M.K.; ELLIOT, K.S. Determinação teórico-experimental da relação momento-rotação em ligações viga-pilar de estruturas pré-moldadas de concreto. V Simpósio EPUSP sobre estruturas de concreto. São Paulo: EPUSP, 2003.

[2] FERREIRA, M. A.; ARAÚJO, D. L.; JEREMIAS Jr, A. C.; CATOIA, B.; KATAOKA, M. N. Estabilidade global de estruturas pré-moldadas: efeito das ligações semi-rígidas. In: 10 Encontro Nacional de Pesquisa-Projeto-Produção em Concreto Pré-Moldado. São Carlos, 2005.

[3] ARAÚJO, D.L.; FERREIRA, M.A.; EL DEBS, M.K. Estabilidade global de estruturas reticuladas em concreto pré-moldado: influência da plastificação da ligação. Revista Sul-Americana de Engenharia Estrutural, v. 3, n.2, p. 85-102, 2006.

[4] EL DEBS, M. K.; MIOTTO, A. M.; EL DEBS, A. L. H. C. Analysis of a semi-rigid connection for precast concrete. Buildings and Structures, p. 41-51, 2010.

[5] HANSON, N.W. Seismic resistance of concrete frames with grade 60 reinforcement. Journal of the Structural Division, 97(6): 1685-700, 1971.

[6] PAULAY, T.; SCARPAS, A. The behaviour of exterior beamcolumn joints. Bulletin of the New Zealand National Society for Earthquake Engineering, 14(3): 131-44, 1981.

[7] FILIPPOU, F.C.; POPOV, E.P.; BERTERO, V.V. Effects of bond deterioration on hysteretic behavior of reinforced concrete joints. Report No. UCB/EERC-83/19. Earthquake Engineering Research Center. 1983.

[8] PAULTRE, P.; CASTELE, D.; RATTRAY, S.; MITCHELL, D. Seismic response of reinforced concrete frame subassemblages - a Canadian code perspective. Canadian Journal of Civil Engineering, 16: 627-49, 1989.

[9] ALAMEDDINE, F.; EHSANI, M.R. High strength RC connections subjected to inelastic cyclic loading. Journal of Structural Engineering, 117(3): 829-50, 1991. 
[10] FILIPPOU, F.C; ISSA, A. Nonlinear analysis of reinforced concrete frames under cyclic load reversals. Report No. UCB/EERC-88/12. Earthquake Engineering Research Center. 1988.

[11] FILIPPOU, F.C; D'AMBRISI, A.; ISSA, A. Nonlinear static and dynamic analysis of reinforced concrete subassemblages. Report No. UCB/EERC-92/08. Earthquake Engineering Research Center. 1992.

[12] MERGOS, P.E.; KAPPOS, A.J. A gradual spread inelasticity model for R/C beam-columns, accounting for flexure, shear and anchorage slip. Engineering Structures, 44: 94-106, 2012.

[13] GHOBARAH, A.; BIDDAH, A. Dynamic analysis of reinforced concrete frames including joint shear deformation. Engineering Structures, 21: 971-87, 1999.

[14] LOWES, L.N.; ALTOONTASH, A. Modeling reinforced-concrete beam-column joints subjected to cyclic load. Journal of Structural Engineering, 129(12): 1686-97, 2003.

[15] BIRELY, A.C; LOWES, L.N.; LEHMAN, D.E. A model for the practical nonlinear analysis of reinforced-concrete frames including joint flexibility. Engineering Structures, 34: 455-65, 2012.

[16] SEZEN, H.; MOEHLE, J.P. Bond-slip behavior of reinforced concrete members. In: fib-Symposium (CEB-FIP) - Concrete Structures in Seismic Regions. Athens, Greece, 2003.

[17] SEZEN, H.; SETZLER, E.J. Reinforcement slip in reinforced concrete columns. ACI Structural Journal, 105(3): 280-9, 2008.

[18] KWAK, H.G.; KIM, S.P. Simplified monotonic moment-curvature relation considering fixed-end rotation and axial force effect. Engineering Structures, 32: 69-79, 2010.

[19] FERREIRA, M. A. Deformabilidade de ligações viga-pilar de concreto pré-moldado. 1999. 231p. Tese (Doutorado) Escola de Engenharia de São Carlos, Universidade de São Paulo, São Carlos, 1999.

[20] ALVA, G. M. S. Estudo teórico-experimental do comportamento de nós de pórtico de concreto armado submetidos a ações cíclicas. 2004. 218p. Tese (Doutorado) - Escola de Engenharia de São Carlos, Universidade de São Paulo, 2004.

[21] ALVA, G. M. S.; EL DEBS, A. L. H. C. Moment-rotation relationship of RC beam-column connections: Experimental tests and analytical model. Engineering Structures, v. 56, p. 1427-1438, 2013.

[22] ALVA, G. M. S.; FERREIRA, M. A.; EL DEBS, A. L. H. C. Engastamento parcial de ligações viga-pilar em estruturas de concreto armado. Revista IBRACON de Estruturas e Materiais, v. 2, n. 4, p.356-379, 2009.

[23] MONFORTON, G.R; WU, T.S. Matrix analysis of semi-rigidly connected frames. Journal of the Structural Division, (ASCE), v.89, p.13-42, dezembro de 1963.

[24] ASSOCIAÇÃO BRASILEIRA DE NORMAS TÉCNICAS. NBR 9062: Projeto e execução de estrururas de concreto pré-moldado. Rio de Janeiro: ABNT, 2017.

[25] ASSOCIAÇÃO BRASILEIRA DE NORMAS TÉCNICAS. NBR 6118: Projeto de estruturas de concreto - Procedimento. Rio de Janeiro: ABNT, 2014.

[26] BOROSNYOÍ, A; BALÁZS, G.L. Models for flexural cracking in concrete: the state of the art. Structural Concrete 2005; 6(2): 53-62.

[27] EUROPEAN COMMITTEE FOR STANDARDIZATION. EUROCODE 2: Design of Concrete Structures - Part 1: General Rules and Rules for Building. Brussels, 2004.

[28] ASSOCIAÇÃO BRASILEIRA DE NORMAS TÉCNICAS. NBR 6120: Cargas para o cálculo de estruturas de edificações. Rio de Janeiro: ABNT, 1980.

[29] LEE, L.N.; WIGHT, J.K.; HANSON, R.D. RC beam-column joints under large load reversals. Journal of the Structural Division 1977; 103(12): 2337-50.

[30] LACERDA, M. M. S. Análise da influência do grauteamento e da posição das armaduras na ligação viga-pilar em estruturas de concreto pré-moldado. 171 p. Dissertação (Mestrado) - Faculdade de Engenharia Civil, Universidade Federal de Uberlândia, 2016. 